\title{
Wood Chemical Compositions of Raru Species Originating from Central Tapanuli, North Sumatra, Indonesia: Effect of Differences in Wood Species and Log Positions ${ }^{1}$
}

\author{
Apri Heri ISWANTO $\mathbb{D}^{2,3, \dagger} \cdot$ Fazilla Oktaviani TARIGAN ${ }^{4} \cdot$ \\ Arida SUSILOWATI ${ }^{3,5} \cdot$ Atmawi DARWIS $^{6} \cdot$ Widya FATRIASARI $^{7}$
}

\begin{abstract}
Raru is a lesser-known plant species originating from North Sumatra, Indonesia. Information on the characteristics is still limited, especially its chemical component. Therefore, this study aims to examine the chemical composition information of Cotylelobium lanceolatum, Cotylelobium melanoxylon, and Vatica pauciflora woods based on their axial log positions (bottom, middle, and top). The wood chemical analysis was performed in terms of the Indonesian National Standard (SNI) method. Furthermore, the analysis measured holocellulose, $\alpha$-cellulose, hemicellulose, lignin content, alcohol benzene extractive content, the extractive substance in hot and water, and solubility in $\mathrm{NaOH} 1 \%$. The results indicated that the species and their log axial positions affected different chemical components, which included $\alpha$-cellulose, hemicellulose, and lignin of $C$. lanceolatum amounting to $41.88 \%$, $19.39 \%$, and $28.68 \%$ respectively. Meanwhile, for C. Melanoxylon, they were $42.01 \%, 21.11 \%$, and $24.76 \%$ respectively; and for $V$. pauciflora wood, they were $42.95 \%, 23.24 \%$, and $30.11 \%$ respectively. The average values of the extractive contents including the solubility in 1: 2 ethanol benzene, $\mathrm{NaOH}$, and hot water for C. lanceolatum, C. melanoxylon, and $V$. pauciflora wood were $(10.58 \%, 27.62 \%, 8.13 \%),(14.54 \%, 28.22 \%, 7.82 \%)$, and $(10.95 \%$, $28.60 \%, 7.57 \%)$ respectively. The wood species had a significant effect on chemical components including lignin, cellulose and hemicellulose, and extractive solubility in cold water. Furthermore, the axial log position had a significant effect on all the parameters of the chemical composition of the wood being tested.
\end{abstract}

Keywords: raru wood, chemical component, C. lanceolatum, C. melanoxylon, V. pauciflora

${ }^{1}$ Date Received May 24, 2021, Date Accepted July 17, 2021

2 Department of Forest Product, Faculty of Forestry, Universitas Sumatera Utara. Kampus USU Padang Bulan, Medan 20155, North Sumatra, Indonesia

3 JATI-Sumatran Forestry Analysis Study Center, Jl. Tridharma Ujung No.1, Kampus USU, Medan, North Sumatra, Indonesia

${ }^{4}$ Graduate Student, Faculty of Forestry, Universitas Sumatera Utara. Kampus USU Padang Bulan, Medan, North Sumatra, Indonesia

${ }_{5}^{5}$ Department of Silviculture, Faculty of Forestry, Universitas Sumatera Utara. Kampus USU Padang Bulan, Medan 20155, North Sumatra, Indonesia

${ }^{6}$ School of Life Sciences and Technology, Institut Teknologi Bandung. Gedung Labtex XI, Jalan Ganesha 10, Bandung 40132, West Java, Indonesia

${ }^{7}$ Research Center for Biomaterials LIPI, Bogor, Indonesia

$\dagger$ Corresponding author: Apri Heri ISWANTO (e-mail: apri@usu.ac.id, ORCID: 0000-0002-4243-1429) 
Wood Chemical Compositions of Raru Species Originating from Central Tapanuli, North Sumatra, Indonesia: Effect of Differences in Wood Species and Log Positions

\section{INTRODUCTION}

Indonesia is well known to have a very high level of biodiversity, especially in terms of its vegetation diversity. One of the provinces with high biodiversity is North Sumatra. It has a tropical forest area with a relatively high level of species diversity and with several local vegetation, which may be studied for their characteristics. The forest area is around 3,010,160.89 ha or $41.25 \%$ of the total land area of North Sumatra Province. Several plant species are local commodities of North Sumatra, namely Kemenyan (Styrax sumatrana, Styrax benzoin Dryan, Styrax benzoine var. Hiliferum), Dryobalanop aromatica, Raru (Cotylelobium melanoxylon, Cotylelobium lanceolatum, Vatica pauciflora), etc. The characteristics of some local species have not been studied.

Several studies were conducted by Iswanto et al. (2016) regarding the physical and mechanical properties of three species of Styrax wood originating from North Tapanuli, and the chemical composition based on the differences in the growth location of Styrax sumatrana was also studied. A study was conducted on the potential of styrax resin as an antioxidant and the cinnamic acid content found in the styrax resin of North Tapanuli (Hidayat et al., 2018; Kiswandono et al., 2019). In other related studies, Susilowati et al. (2018) and Rahmat et al. (2017) detailed the genetics of styrax grown in North Sumatra, Indonesia. It was reported that the styrax plant can be used for other purposes, such as medicine, perfume, cosmetics, etc.

The Raru plants are the other plant species that can be further studied in the forest areas of North Sumatra. Based on the available information, particularly of the Central Tapanuli area, there are three species of Raru producing plants (Susilowati et al., 2020; Elfiati et al., 2019). They include Dahanon (Cotylelobium lanceolatum), Songal (Vatica panciflora), and Pulut (Cotylelobium melanoxylon). Hildebrand (1954) showed that there are several species of wood classified as raru producing plants, including Shorea maxwelliana King, Vatica songa V.Sl. from the Dipterocarpaceae, and Garcinia $s p$. from the Guttifera family.

Generally, the bark of raru wood is used to improve the taste and the alcohol content of Bataknese traditional toddy beverage (Susilowati et al., 2019), antihyperuricemic, and antioxidant (Sinaga et al., 2020). The wood is suitable for heavy material constructions, such as electricity poles, and in ship-building (Susilowati et al., 2020). Furthermore, it can be used as natural food preservatives due to its high tannin content (Pasaribu, 2007). However, there is limited information related to the basic properties of this wood. The data found were still limited in terms of the physical, mechanical, and chemical properties of Raru $C$. Melanoxylon as reported by Pasaribu (2007) and Pasaribu et al. (2007).

As an effort to optimize the use of the wood, information related to the characteristics is required. Several basic properties have an important role in the use of wood as raw material. One of which is the chemical component consisting of cellulose, hemicellulose, lignin, and extractives. Henriksson et al. (2009) reported that the chemical properties, which include cellulose, extractive, and lignin content, are some of the properties that have an impact on pulp and paper production. Furthermore, the chemical properties are also important and should be considered because they are associated with several uses. In the form of cellulose content, these properties can be a reference for using wood as a bioethanol material (Demirbas, 2005). The chemical properties serve as a reference for the use of wood as a pulp and paper material (Sjöström, 1993). The chemical properties in lignin and cellulose content affect the heating value of wood (Bowyer et al., 2003; Lee et al., 2019). Furthermore, the properties can be considered for any purpose such as the cellulose for capacitor material (Li et al., 2019) 
Apri Heri ISWANTO $\cdot$ Fazilla Oktaviani TARIGAN $\cdot$ Arida SUSILOWATI $\cdot$ Atmawi DARWIS $\cdot$ Widya FATRIASARI

to replace the use of ink on plastics with colored films (Tzeng et al., 2015), and as a raw material for 3D printing ink (Mietner et al., 2021). The lignin can be utilized for raw material in wastewater treatment (Xiao et al., 2019; Maulina et al., 2020; Fatriasari et al., 2020), biomedicine (Siddiqui et al., 2018), biorefinery (Liu et al., 2019; Yang et al., 2019), paint and coating (Zikeli et al., 2019), and packaging (Xing et al., 2019).

This study focused on examining the effect of wood species and the axial position of the stem on its chemical components. These two factors play an important role in determining the diversity of chemical components of wood. The variation of the chemical properties was affected by species differences and log positions. In addition, (González-Rodrigo et al., 2013) reported that phenotypic and genotypic factors cause a high variability in wood properties between different and individuals of the same species. Individual variations are not apparent but resulted from a complex system of various factors involved in modifying the physiological processes of wood formation. Previous studies showed that there are various properties such as a chemical component of lignocellulosic materials including wood. Meanwhile, Lestari et al. (2016) reported that the extractive content of platinum teak wood is significantly affected by tree age and axial position in the stem. Pettersen (1984) further claimed that chemical component variations are influenced by wood section (roots, stems, and branches), species, growing location, climate, and soil conditions. The chemical makeup differs from pith to bark, from stump to crown, from earlywood and latewood, and between sapwood and heartwood in each portion of a single tree (Kollmann and Cote, 1984). In addition, genetic factors and tree age also have an impact on the chemical composition of wood (Berrocal et al., 2004). Therefore, an axial study of the chemical properties of Raru wood based on the log positions was conducted. This study aimed to analyze the chemical composition of three species of Raru wood (C. lanceolatum, C. melanoxylon, and V. pauciflora) originating from Central Tapanuli, North Sumatra, Indonesia based on the axial positions of the logs.

\section{MATERIALS and METHODS}

\subsection{Materials}

Raru wood species of $C$. lanceolatum, $V$. pauciflora, and $C$. melanoxylon were collected from Central Tapanuli Regency, North Sumatra Province ( $1^{\circ} 11^{\prime} 00^{\prime \prime}-2^{\circ} 22^{\prime}$ $0^{\prime \prime}$ north latitude, and $98^{\circ} 07^{\prime}-98^{\circ} 12^{\prime}$ east longitude). They were $C$. lanceolatum, $V$. pauciflora, and C. melanoxylon with the criteria of a tree diameter greater than $15 \mathrm{~cm}$. In addition, only one tree was used for each species and was converted into three log sections after been felled. Fig. 1 showed the base, middle, and top of the wood.

\subsection{Methods}

\subsubsection{Samples preparation}

The samples were then ground with a ring flaker for over $40 \mathrm{mesh}$, then oven-dried with a maximum temperature of $40^{\circ} \mathrm{C}$. They were then stored in sealed plastic containers for further testing, as shown in Fig. 2. The preparation was based on the Indonesia National

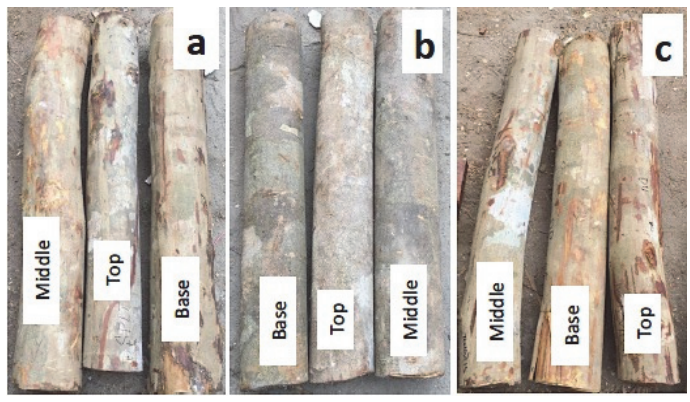

Fig. 1. (a) C. melanoxylon, (b) $V$. pauciflora, and (c) C. lanceolatum based on $\log$ axial direction. 
Wood Chemical Compositions of Raru Species Originating from Central Tapanuli, North Sumatra, Indonesia: Effect of Differences in Wood Species and Log Positions

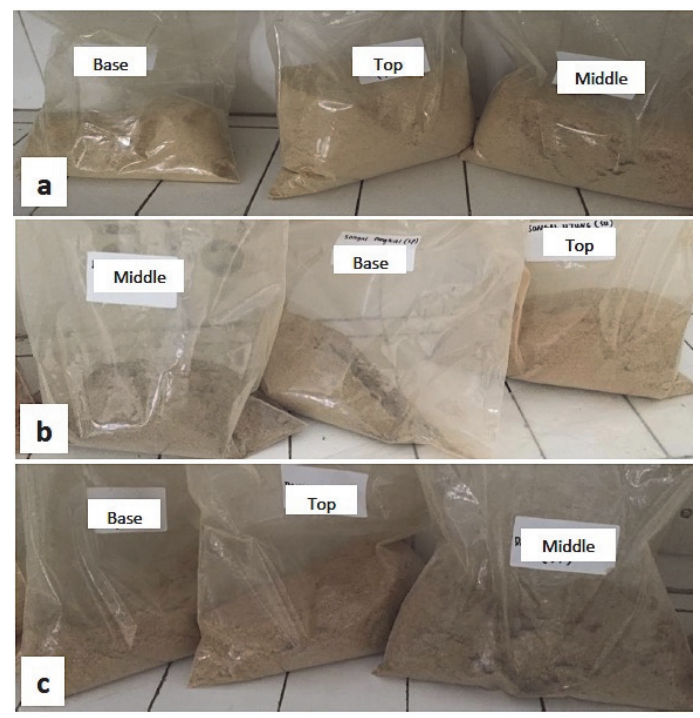

Fig. 2. Samples for chemical analysis of (a) $C$. melanoxylon., (b) V. pauciflora, and (c) C. lanceolatum based on $\log$ axial direction.

Standard (SNI 08-7070: 2005). For chemical component analysis, the moisture content was determined using an oven which was set at a temperature of 105 $\pm 3^{\circ} \mathrm{C}$ for $24 \mathrm{~h}$, and it ranged from $2-4 \%$ for lignin analysis, $3-6 \%$ for ethanol and benzene, and $1-2 \%$ for alpha-cellulose.

\subsubsection{Analysis of wood chemical component}

The chemical component analysis was performed based on the Indonesian National Standard (SNI). This standard was used to determine the chemical components of wood (Hastuti et al., 2017; Purwita and Sugesty, 2018; Jasni et al., 2016). The analysis was observed following the structural chemical compositions of the cell wall, such as Acid-insoluble lignin (SNI 8429: 2017), alpha-cellulose (SNI 8400: 2017), and holocellulose (ASTM D1104-56). Furthermore, extractives content as a non-structural chemical component was also observed. The extractive in alcohol benzene was performed based on SNI 8401:2017, and its solubility in cold and hot water, as well as $1 \%$
$\mathrm{NaOH}$, was referred to the SNI 01-1305-1989 and SNI 14-1838-1990.

\subsubsection{Lignin content}

In the $50 \mathrm{~mL}$ cup, about $1.0 \pm 0.1 \mathrm{~g}$ free ethanol benzene extracted samples were placed, and $15 \mathrm{~mL}$ of $72 \%$ sulfuric acid was added and stirred for 2-3 min until fully dispersed. Furthermore, $300 \mathrm{~mL}$ of distilled water was added to a $1000 \mathrm{~mL}$ Erlenmeyer, and water was applied until the amount reached $575 \mathrm{~mL}$, at which point the sulfuric acid concentration reached $3 \%$. The solution was heated and the temperature was maintained for $4 \mathrm{~h}$ with a constant volume. Meanwhile, the deposit was separated and washed with hot water until acid-free, then precipitated in an oven at $105 \pm 3^{\circ} \mathrm{C}$.

\subsubsection{Holocellulose content}

A $2 \mathrm{~g}$ sample of the ethanol-benzene extracted was weighted and washed with hot water before the benzene alcohol solution was removed. It was wetted with cold water $\left(10^{\circ} \mathrm{C}\right)$ and placed in a filtering paper containing the sample in the chlorination apparatus and chlorinated for $3 \mathrm{~min}$. The filtering paper was then carefully stirred, and the chlorination was repeated for $2 \mathrm{~min}$ before being washed with $95 \%$ alcohol to dissolve the excess chlorine gas and $\mathrm{HCl}$. After $1 \mathrm{~min}$, a vacuum pump was used to remove the solution and moistened with cold water. In addition, menoethanolamine 3\% ( $75^{\circ} \mathrm{C}$ ) was added and left for $2 \mathrm{~min}$ before removing the solution with a vacuum pump. This step was repeated once more, and the residue was washed twice with $95 \%$ alcohol and twice with cold water. The solvent was extracted from each washing by using a vacuum pump, and the chlorination was repeated every 2-3 min, followed by two washes with $95 \%$ alcohol to extract the alcohol-monoethanol solution. The residue was washed two more times with cold water and 95\% alcohol until it was no longer acidic. Furthermore, ether was added to speed up the drying process, and the resi- 
Apri Heri ISWANTO $\cdot$ Fazilla Oktaviani TARIGAN $\cdot$ Arida SUSILOWATI $\cdot$ Atmawi DARWIS $\cdot$ Widya FATRIASARI

due-filled filtering paper was oven dried for $2.5 \mathrm{~h}$ at $105 \pm 3^{\circ} \mathrm{C}$, then cooled in the desiccator and weighed.

\subsubsection{Alpha-Cellulose Content}

The Alpha-Cellulose content was determined by weighing $1.5 \pm 0.1 \mathrm{~g}$ and placing it in a $300 \mathrm{~mL}$ cup glass with $75 \mathrm{~mL}$ of $17.5 \% \mathrm{NaOH}$ solution, which was heated in a $25 \pm 0.2^{\circ} \mathrm{C}$ until the sample was dispersed. To make a $100 \mathrm{~mL}$ complete solution, $25 \mathrm{~mL}$ of $17.5 \% \mathrm{NaOH}$ solution was added. After $30 \mathrm{~min}$ of the first $\mathrm{NaOH}$ solution addition, $100 \mathrm{~mL}$ of aquades was added and left in the hot plate stirrer for $30 \mathrm{~min}$ until the total extraction time is approximately $60 \mathrm{~min}$. After that, $25 \mathrm{~mL}$ of the filtrate and $10 \mathrm{~mL}$ of 0.5 $\mathrm{N}$ potassium dichromate solution were put into a 250 $\mathrm{mL}$ flask, then $50 \mathrm{~mL}$ of concentrated $\mathrm{H}_{2} \mathrm{SO}_{4}$ was added. The solution was left for $15 \mathrm{~min}$ in the hot plate stirrer. Furthermore, $50 \mathrm{~mL}$ of aquades was added and left to cool, and 2-4 drops of pheromoin indicator were titrated with $0.1 \mathrm{~N}$ ferro ammonium sulfate solution until purple. The filtrate was replaced with $12.5 \mathrm{~mL}$ of $17.5 \% \mathrm{NaOH}$ solution and $12.5 \mathrm{~mL}$ of aquades for the blank titration.

\subsubsection{Extractives content in ethanol-benzene of $1: 2$}

About $1 \pm 0.1 \mathrm{~g}$ of sample powder (40-60 mesh) was weighed in a petri dish, and then samples were put in the filtering paper, covered and tied. The soluble fraction in ethanol benzene of samples was then calculated. Following that, the samples were put in a $250 \mathrm{~mL}$ soxhlet apparatus (the initial weight was determined), and 150-200 mL of a 1:2 alcohol-benzene mixture was applied. This apparatus was connected to the cooler and extracted in a water bath for $6 \mathrm{~h}$, with five circulations per hour. Furthermore, the filtering paper containing samples was removed from the apparatus, and the extraction solution was steamed until nearly dry. The residual evaporation was heated in pumpkin extraction at $105^{\circ} \mathrm{C}$ for $3 \mathrm{~h}$ or more.

\subsubsection{Hot water extractive content}

A total of $2.0 \pm 0.1 \mathrm{~g}$ of oven-dried samples were inserted into the $200 \mathrm{~mL}$ Erlenmeyer flask and 100 $\mathrm{mL}$ water was added before placing the cooler upright. In addition, the sample-containing Erlenmeyer was placed in a water bath containing boiling water for 3 $h$, with the surface in the bath set to be higher than that in the Erlenmeyer. The sample was filtered with a mouthpiece filtering paper considered to weigh after Erlenmeyer was removed from the water bath. Furthermore, the filtrate was then washed with hot water until it was clear, and the residue was then dried in a $105 \pm 3^{\circ} \mathrm{C}$ oven for $4 \mathrm{~h}$ before being cooled in a desiccator and measured.

\subsubsection{Cold Water extractive content}

A total of $2.0 \pm 0.1 \mathrm{~g}$ of oven-dried samples was inserted into a $400 \mathrm{~mL}$ cup glass and added $300 \mathrm{~mL}$ of water. The solution was stirred and placed at a room temperature of $23 \pm 2^{\circ} \mathrm{C}$ for $48 \mathrm{~h}$. Also, the sample was filtered with a masir funnel and washed with cold water until the filtrate was clear. The funnel containing the sample residue was oven-dried at a temperature of $105 \pm 3^{\circ} \mathrm{C}$ for $4 \mathrm{~h}$ then cooled in a desiccator and weighed.

\subsubsection{Extractives content in the $1 \% \mathrm{NaOH}$}

$2.0 \pm 0.1 \mathrm{~g}$ of oven-dried sample was transferred into a $200 \mathrm{~mL}$ cup glass, and $100 \mathrm{~mL}$ of $1 \% \mathrm{NaOH}$ solution was added and stirred in a closed glass cup. For $60 \mathrm{~min}$, it was put in a water bath containing boiling water and positioned where water in the handler was higher than the surface of the $\mathrm{NaOH}$ solution in the cup glass. The sample was filtered with a mouthpiece filtering paper that was known to weigh after the cup glass containing the sample was removed from the water bath. Furthermore, it was washed with hot water until the filtrate was colorless. $25 \mathrm{~mL}$ of $10 \%$ acetic acid was applied and allowed to stand for $1 \mathrm{~min}$ before re-filtration, and the items used were washed 
Wood Chemical Compositions of Raru Species Originating from Central Tapanuli, North Sumatra, Indonesia: Effect of Differences in Wood Species and Log Positions

in hot water until they were acid-free. The glass containing the sample was removed from the water bath, and the sample was filtered with a mouthpiece filtering paper used for weighing. The funnel containing the sample residue was dried at $105 \pm 3^{\circ} \mathrm{C}$ for $4 \mathrm{~h}$ before being cooled in a desiccator and weighed.

\subsection{Statistical Analysis}

A completely factorial randomized design consisting of factors A and B was used. Factor A includes the three species of wood (C. lanceolatum, $V$. pauciflora, and $C$. melanoxylon), and factor B includes the three positions of the stem in the axial direction (base, middle, and top). The sample analysis for the chemical component was carried out in duplo for each treatment. Therefore, the total sample analyzed was 18 units. Analysis of Variance (ANOVA) test at a 95\% confidence interval was conducted to determine whether this treatment provided a real difference or not to the chemical component parameters tested.

\section{Results and Discussion}

\subsection{Structural Chemical Composition}

The average value of structural chemical composition was presented in Table 1.

\subsubsection{Lignin}

The lignin content based on the axial direction ranges from $22.77(\mathbf{1 . 0 9})$ - $31.25(\mathbf{0 . 2 1}) \%$, and the highest was located in the middle part of $V$. pauciflora wood, while the lowest was found in the top part of $C$. melanoxylon wood. The highest and lowest lignin content of all wood species was located in the middle and top part of the $\log$. This result was contrary to a previous study conducted by Rahman et al. (2018) concerning lignin content in Kelampayan wood. It was reported that the highest lignin content was located in the top position because it was dominated by juvenile wood. Furthermore, raru wood was not significantly different concerning specific gravity at the base (1.07), middle (0.97), and top (0.93). The three positions are included in the category of high specific gravity since the phenomenon of the influence of juvenile wood on kelampayan as proposed by Rahman et al. (2018) does not occur in this raru wood.

Pasaribu (2007) showed that the specific gravity of C. melanoxylon wood at the three log's position of the base, middle, and top trunk ranged from 1.02 to 1.09. The highest and lowest value was located in the base and then the top respectively.

All parts of $V$. pauciflora contain lignin, which showed that the wood has better strength than the other species. Lignin contributes to the stiffness of cell walls (Gindl et al., 2002), and Fagerstedt et al. (2015) stated

Table 1. Structural chemical composition of Raru wood

\begin{tabular}{lccccc}
\hline Wood Species & Log Position & Lignin & Holocellulose & Alpha Cellulose & Hemicellulose \\
\hline \hline C. lanceolatum & Base & $28.78(0.68)$ & $61.78(1.10)$ & $42.44(0.08)$ & $19.34(0.48)$ \\
& Middle & $29.62(1.73)$ & $61.03(0.04)$ & $41.6(0.85)$ & $19.43(0.47)$ \\
& Top & $27.66(0.65)$ & $61.03(0.04)$ & $41.62(0.74)$ & $19.62(0.45)$ \\
V. pauciflora & Base & $31.13(0.47)$ & $62.24(0.34)$ & $41.3(0.68)$ & $20.94(0.62)$ \\
& Middle & $31.25(0.21)$ & $67.34(0.48)$ & $44.26(0.51)$ & $23.08(0.37)$ \\
& Top & $27.97(0.81)$ & $69.00(0.85)$ & $43.29(0.41)$ & $25.71(0.44)$ \\
C. melanoxylon & Base & $25.23(0.33)$ & $62.60(0.85)$ & $40.60(1.56)$ & $22.00(0.28)$ \\
& Middle & $26.30(0.42)$ & $67.20(0.28)$ & $44.99(1.12)$ & $22.21(0.30)$ \\
& Top & $22.77(1.09)$ & $59.59(0.83)$ & $40.46(1.50)$ & $19.13(0.18)$ \\
\hline
\end{tabular}


that it provides resistance to the comprehensive force of structures.

Referring to the classification introduced by the Ministry of Environment and Forestry (2020), the lignin content was classified into the moderate category. Therefore, the three wood species can still be used as raw materials for pulp and paper. According to Martawijaya et al. (2005), the lignin content in wood commonly ranges from $18-33 \%$, and a high content is not desirable in wood utilization for pulp and paper and bioenergy. This is because it needs to increase the pulp quality or accessibility of enzymes into cellulose. Lignin is the second-largest substance and one of the main chemical components in plants (Casey, 1980). It functions as a binding agent between cells and provides rigidity Ray et al. (2009). According to Terashima et al. (2009), lignin plays an essential role in the structural assembly of a cell wall.

The lignin content of these three wood species is almost the same as that of Acacia mangium, which ranges from 28-32\% (Siagian et al., 2009), Shorea retusa, Shorea macroptera, and Eucalyptus pelita contents range from 26-31\%, 24-31\% (Yunanta et al., 2014; Lukmandaru et al., 2016), and 22-36\% (Fatimah et al., 2013) respectively. They have a higher content when compared to Styrax sumatrana, Ceiba pentandra, and Ochroma pyramidale (Iswanto et al., 2019; Purnamawati et al., 2018). When compared with several subtropical wood species such as Larch, Red pine, Korean pine, Cypress, and Cedar as reported by Park et al. (2017), the lignin content of the three species of Raru wood is almost similar.

The analysis of variance (ANOVA) showed that the interaction between wood species and log position does not significantly affect the $95 \%$ confidence interval on lignin content. However, for a single wood species factor, it has a significantly different effect.

\subsubsection{Holocellulose}

The holocellulose content of the three observed wood species with an axial direction of log ranged from $59.59(\mathbf{0 . 8 3})$ to $69.00(\mathbf{0 . 8 5}) \%$. Meanwhile, the highest holocellulose content was found in the top part of $V$. pauciflora wood, and the lowest was seen in the bottom part of $C$. melanoxylon. According to Fengel and Wegener (1984), a small percentage of lignin remains in holocellulose. This is because there is an ultrastructural and chemical relationship between cell wall macromolecules, such as holocellulose and lignin.

This is slightly different from the result obtained from the study conducted by Rahman et al. (2018). It was reported that kelampayan wood, one of the fastest-growing species, had a holocellulose content ranging from 68 to $70 \%$. Most of the cells are dominated by juvenile wood, which has a higher cellulose content. Furthermore, high cellulose affects the high holocellulose content, and the three Raru wood species were not classified as fast-growing wood due to their high specific gravity value.

Based on the species variety, C. melanoxylon wood has the highest holocellulose content in all positions. Therefore, it is predicted to have a higher pulp yield than $V$. pauciflora and $C$. lanceolatum. Most of the three Raru wood species contain high holocellulose content ( $>65 \%$ ), which produces good pulp characteristics and a high yield pulp (Fatriasari and Hermiati, 2008). A high proportion of polysaccharides showed a high holocellulose content, which will increase the pulp yield (MacLeod, 2007).

The analysis of variance (ANOVA) showed that the interaction of wood species with $\log$ position has a significantly different effect at a $95 \%$ confidence interval on holocellulose content.

\subsubsection{Alpha-cellulose}

Material with a higher alpha-cellulose content has high-quality raw material (Sumada et al., 2011). The 
Wood Chemical Compositions of Raru Species Originating from Central Tapanuli, North Sumatra, Indonesia: Effect of Differences in Wood Species and Log Positions

cellulose content of Raru wood ranges from 40.46 (1.50) - 44.99 (1.12)\%. This is consistent with Pettersen (1984), stating that the cellulose content of dry wood weight ranges from 40-50\%. Generally, the wood growth environment contributes to variation of wood's chemical composition, including cellulose (Fatriasari et al., 2019).

The higher content of cellulose is found in the middle position. The highest and the lowest alpha-cellulose contents are located in the middle and the top position of $C$. melanoxylon wood. Meanwhile, the purity is often expressed in the alpha-cellulose content. A high cellulose content showed strong fiber, relatively resistant in separation and purification to chemicals. It is also insoluble in neutral organic solvents and water (Casey, 1980). High alpha-cellulose such as cellulose nitrite, carboxyl methylcellulose, and cellulose xanthate is needed in making filter paper (Fengel and Wegener, 1984).

The three Raru wood species have almost similar cellulose contents and are presumably affected by the high specific gravity category $(>0.8)$. They have almost the same proportion of mature wood since the cellulose content does not differ. Furthermore, Ona et al. (1998) reported that the specific gravity of wood is positively correlated with cellulose content. The Indonesian wood classification assessment for pulp and paper material Ministry of Environment and Forestry (2020) showed that the cellulose content of Raru wood can be categorized into medium class.

The analysis of variance (ANOVA) showed that the interaction of wood species with $\log$ position has a significantly different effect at a $95 \%$ confidence interval on alpha-cellulose content.

\subsubsection{Hemicellulose}

The hemicellulose content of the three Raru wood species ranges from $19.13(\mathbf{0 . 1 8})$ - $25.71(\mathbf{0 . 4 4}) \%$. Meanwhile, the highest and the lowest hemicellulose contents were found on the top $\log$ of $V$. pauciflora and $C$. melanoxylon respectively. This value was slightly lower than the hemicellulose content of Styrax sumatrana wood. Iswanto et al. (2019) also reported that Styrax sumatrana wood has a hemicellulose content ranging from 26-29\%. Syafii and Siregar (2006) reported that a hemicellulose content with good criteria for pulp and paper raw materials ranges from 15 - 25\%. A high hemicellulose content has an essential role in milling the pulp (Stephenson, 1951). It creates more flexible fiber, and it is critical to the fibrillation process. Besides, the fiber would be more plastic because of higher water absorption. This condition causes a high surface area formation during pulp formation Fatriasari and Hermiati (2008). This is due to the gelatin properties of hemicellulose, which facilitates the hydrophilic character of the pulp and facilitates the formation of bonds between fibers.

The analysis of variance (ANOVA) showed that the interaction of wood species with $\log$ position has a significantly different effect at a $95 \%$ confidence interval on hemicellulose content.

\subsection{Non-Structural Chemical Composition}

The average value of non-structural chemical composition was presented in Table 2 .

\subsubsection{Extractive Substances in Alcohol Benzene 1:2}

The extractive substances are dissolved in both polar and non-polar solvents such as an alcohol-benzene solution of 1: 2. C. melanoxylon had the highest value in alcohol-benzene of 1:2 on the base, middle, and top positions with $14.18(\mathbf{0 . 2 5}) \%, 14.92(\mathbf{0 . 8 8}) \%$, and $14.51(\mathbf{0 . 5 8}) \%$ respectively. These values increased up to $5 \%$, which can be included in high solubilization. In addition, it is less suitable to form good pulp properties (Fatriasari et al., 2015) based on the assessment 
Apri Heri ISWANTO $\cdot$ Fazilla Oktaviani TARIGAN $\cdot$ Arida SUSILOWATI $\cdot$ Atmawi DARWIS $\cdot$ Widya FATRIASARI

Table 2. Non-structural chemical composition of Raru wood

\begin{tabular}{lccccc}
\hline Wood Species & Log Position & Alcohol Benzene & $1 \%-\mathrm{NaOH}$ & Hot Water & Cold Water \\
\hline \hline C. lanceolatum & Base & $10.07(0.10)$ & $28.16(0.23)$ & $6.57(0.66)$ & $3.13(0.18)$ \\
& Middle & $9.84(0.91)$ & $26.87(0.95)$ & $7.57(0.66)$ & $2.52(0.45)$ \\
& Top & $11.84(0.91)$ & $27.84(0.91)$ & $8.13(0.18)$ & $4.39(0.41)$ \\
V. pauciflora & Base & $9.67(0.81)$ & $28.33(0.47)$ & $7.12(0.17)$ & $4.00(0.28)$ \\
& Middle & $9.40(0.57)$ & $29.71(0.58)$ & $7.87(0.52)$ & $4.12(0.17)$ \\
& Top & $13.79(0.98)$ & $27.76(0.65)$ & $7.72(0.45)$ & $3.39(0.41)$ \\
C. melanoxylon & Base & $14.18(0.25)$ & $29.76(0.65)$ & $7.62(0.45)$ & $2.48(0.54)$ \\
& Middle & $14.92(0.88)$ & $27.67(0.66)$ & $8.15(0.21)$ & $5.27(0.38)$ \\
& Top & $14.51(0.58)$ & $27.22(0.31)$ & $7.70(0.28)$ & $6.05(0.11)$ \\
\hline
\end{tabular}

of Indonesian wood classification for pulp and paper material (Ministry of Environment and Forestry, 2020). The extractive solubility in alcohol-benzene of 1:2 also significantly influences the wood color. Lukmandaru (2016) showed a higher extractive content in alcohol-benzene produces lower brightness of wood, which means the heartwood will be darker. $C$. melanoxylon wood has a higher extractive content and produces the darkest color compared to others. On the contrary, this high value in $C$. melanoxylon wood showed it is more difficult to be converted for pulp. This value needs a high amount of chemicals for the cooking process in the pulping process (Fatriasari and Hermiati, 2008).

The analysis of variance (ANOVA) showed that the interaction of wood species with $\log$ position has a significantly different effect at a $95 \%$ confidence interval on alcohol benzene 1:2 content.

\subsubsection{Extractive Substances in Hot and Cold Water}

Pari et al. (2006); Fengel and Wegener (1984) reported that tannins, gums, sugar, and coloring agents can be dissolved in the extraction using hot and cold water, while starches can only be solubilized by hot water.

Extractive solubility in hot and cold water ranged from $6.57(\mathbf{0 . 6 6})$ to $8.15(\mathbf{0 . 2 1}) \%$ and $2.48(\mathbf{0 . 5 4})$ to $6.05(\mathbf{0 . 1 1}) \%$ respectively. The highest and the lowest values in hot water were found in C. melanoxylon and C. lanceolatum wood respectively. Furthermore, the axial direction showed that the top and the base positions of C. melanoxylon Raru wood log have the highest and the lowest extractive content values dissolved in cold water. Generally, there was no difference in extractive content values based on the axial position of the $\log$ since hot water is a more solubilize extractive substance than cold water. The partial hydrolysis of hemicellulose that involves the development of an organic acid solution into the water may cause it (Dockzekalska et al., 2010). Also, starch solubilization in hot water extraction contributes to the higher values of the content. This is caused by partial hydrolysis of hemicellulose, which involves developing an organic acid solution into water.

The analysis of variance (ANOVA) showed that the interaction between wood species and log position does not significantly affect the $95 \%$ confidence interval. However, the log position has a significantly different effect on the extractive content that dissolves in hot water. For the cold water, the analysis of variance (ANOVA) showed that the interaction of wood species with log position has a significantly different effect at a $95 \%$ confidence interval on extractive con- 
Wood Chemical Compositions of Raru Species Originating from Central Tapanuli, North Sumatra, Indonesia: Effect of Differences in Wood Species and Log Positions

tent that dissolves in cold water.

\subsubsection{Extractive Substances in $\mathrm{NaOH} 1 \%$}

The extractives solubility in $1 \%-\mathrm{NaOH}$ ranged from $26.87(\mathbf{0 . 9 5})$ to $29.76(\mathbf{0 . 6 5}) \%$. In the base position of $C$. melanoxylon wood, the solubility was higher than the others. Furthermore, the $1 \%-\mathrm{NaOH}$ solubility showed the dissolving of wood components in low molecular weight of carbohydrates, tannin, and dyes. The high extractive substances in $1 \%-\mathrm{NaOH}$ solvent indicated that the wood was dominated by inorganic minerals, carbohydrates, fats, oils, dyes, and aromatic compounds (Pari et al., 2006). In pulping process, the extractive substances are expected to be low due to decreased chemical consumption. A high extractive content should be able to produce pitch in the paper sheet.

The analysis of variance (ANOVA) showed that the interaction of wood species with log position has a significantly different effect at a $95 \%$ confidence interval on extractive content that dissolves in $\mathrm{NaOH}$.

\section{CONCLUSION}

- The mean values of chemical components ( $\alpha$ -cellulose, hemicellulose, and lignin) for C. lanceolatum species were $41.88 \%, 19.39 \%$, and $28.68 \%$, respectively. For C. Melanoxylon and $V$. pauciflora the values were $(42.01 \%, 21.11 \%$, $24.76 \%)$ and $(42.95 \%, 23.24 \%, 30.11 \%)$ respectively. Furthermore, the average values of the extractive contents (the solubility in 1:2 ethanol benzene, $\mathrm{NaOH}$, and hot water) for C. lanceolatum, C. melanoxylon, and $V$. pauciflora wood were $(10.58 \%$, $27.62 \%, 8.13 \%),(14.54 \%, 28.22 \%, 7.82 \%)$, and $(10.95 \%, 28.60 \%, 7.57 \%)$ respectively.

-Wood species significantly affect the chemical components such as lignin, cellulose, and hemicellulose, and extractive solubility in cold water. Furthermore, the axial log position has a significant effect on the chemical component tested.

- V. pauciflora wood had the highest cellulose, hemicellulose, and lignin content compared to the other species. The highest extractives solubility in alcohol-benzene, cold and hot water were found in $C$. melanoxylon wood. Meanwhile, the fractionation of structural component of high chemical in raru woods brings more wide range future application such as biorefinery products.

\section{ACKNOWLEDGMENT}

We are grateful to the Directorate General of Higher Education-Ministry of Research, Technology and Higher Education, Republic Indonesia, for funding the research through to Hibah Penelitian Dasar (PD) year of 2019 (No: 11/E1/KP.PTNBH/2019, date: 29 March 2019).

\section{REFERENCES}

American Society for Testing Materials (ASTM). 1978. ASTM D1104-56: Method of Test for Holocellulose in Wood. United States of America.

Berrocal, A., Baeza, J., Rodriguez, J., Espinosa, M., Freer, J. 2004. Effect of tree age on variation of Pinus radiata D. Don chemical composition. Journal of the Chilean Chemical Society 49(3): 251-256.

Bowyer, J.L., Shmulsky, Haygreen, J.G. 2003. Forest Products and Wood Science - An Introduction. Fourth edition. Iowa (US): Iowa State University Pr.

Casey, J.P. 1980. Pulp and Paper Chemistry and Chemical Technology. Third edition.; A WilleyInterscience Publisher Inc: New York, pp. 1-848.

Demirbas, A. 2005. Bioethanol from cellulosic materials: A renewable motor fuel from biomass. Energy Sources 27(4): 327-337.

Dockzekalska, B., Zborowska, M. 2010. Wood chemical 
Apri Heri ISWANTO $\cdot$ Fazilla Oktaviani TARIGAN $\cdot$ Arida SUSILOWATI $\cdot$ Atmawi DARWIS $\cdot$ Widya FATRIASARI

composition of selected fast-growing species treated with $\mathrm{NaOH}$ part II: Non-structural substance. Wood Research 55(3): 83-92.

Elfiati, D., Susilowati, A., Modes, C., Rachmat, H.H. 2019. Morphological and molecular identification of cellulolytic fungi associated with local raru species. Biodiversitas 20(8): 2348-2354.

Fagerstedt, K., Saranpää, P., Tapanila, T., Immanen, J., Serra, J.A.A., Nieminen, K. 2015. Determining the composition of lignins in different tissues of Silver birch. Plants 4(2): 183-195.

Fatimah, S., Susanto, M., Lukmandaru, G. 2013. Studi komponen kimia kayu Eucalyptus pellita F. Muell dari pohon plus hasil uji keturunan generasi kedua di wonogiri, jawa tengah. Jurnal Ilmu Kehutanan 7(1): $57-69$.

Fatriasari, W., Hermiati, E. 2008. Analysis of fiber morphology and physical-chemical properties of six species of bamboo as raw material for pulp and paper. Jurnal Ilmu Teknologi Hasil Hutan 1(2): 67-72.

Fatriasari, W., Supriyanto, Iswanto, A.H. 2015. The kraft pulp and paper properties of sweet sorghum bagasse (Sorghum bicolor L Moench). Journal of Engineering and Technological Sciences 47(2): 149-159.

Fatriasari, W., Masruchin, N., Hermiati, E. 2019. Selulosa: Karakteristik dan Pemanfaatannya. LIPI Press: Indonesia, pp. 1-166.

Fatriasari, W., Nurhamzah, F., Raniya, R., Laksana, R.P.B., Anita, S.H., Iswanto, A.H., Hermiati, E. 2020. Enzymatic hydrolysis performance of biomass by the addition of a lignin based biosurfactant. Journal of the Korean Wood Science and Technology 48(5): 651-665.

Fengel, D., Wegener, G. 1984. Wood, Chemistry, Ultrastructure, Reactions. Walter de Grugter, Berlin New York: USA, pp. 1-613.

Gindl, W., Gupta, H.S., Grunwald, C. 2002. Lignification of spruce tracheid secondary cell walls related to longitudinal hardness and modulus of elasticity using nano-indentation. Canadian Journal of Botany 80(10): 1029-1033.

González-Rodrigo, B., Esteban, L.G., de Palacios, P., García-Fernández, F., Guindeo, Y.A. 2013. Variation throughout the tree stem in the physical-mechanical properties of the wood of Abies alba mill. From The Spanish Pyrenees. Madera Bosques 19(2): 87-107.

Hastuti, N., Efiyanti, L., Pari, G., Saepuloh, Setiawan, D. 2017. Chemical component and potential utilization of five lesser known wood Species Originated from West Java. Jurnal Penelitian Hasil Hutan 35(1): 15-27.

Henriksson, G., Brannvall, E., Lennholm, H. 2009. Wood Chemistry and Wood Biotechnology. In Pulp and Paper Chemistry and Technology. Ek, M., Gellerstedt, G., Henriksson. Walter de Gryuter: Berlin, Germany, pp. 13-44.

Hidayat, A., Iswanto, A.H., Susilowati, A., Rachmat, H.H. 2018. Radical scavenging activity of kemenyan resin produced by an indonesian native plant, Styrax sumatrana. Journal of the Korean Wood Science and Technology 46(4): 346-354.

Hildebrand, F.H. 1954. Daftar Nama Pohon-Pohonan 'Tapanuli' Sumatera Utara. Report of Forest Research Agency No. 67. Forest Research Agency, Bogor, Indonesia.

Indonesia National Standard (SNI). 2017. SNI 8429: Acid-insoluble Lignin in Wood and Pulp (T 222 om-15, IDT). National Standardization Agency of Indonesia.

Indonesia National Standard (SNI). 2017. SNI 8400: Alpha, Beta, and Gamma-cellulose in Pulp. National Standardization Agency of Indonesia.

Indonesia National Standard (SNI). 2017. SNI 8401: Solvent Extractives of Wood and Pulp (T 204 cm-07, IDT). National Standardization Agency of 
Wood Chemical Compositions of Raru Species Originating from Central Tapanuli, North Sumatra, Indonesia: Effect of Differences in Wood Species and Log Positions

Indonesia, 2017.

Indonesia National Standard (SNI). 1989. SNI 01-1305:

Wood, Test Method for Cold Hot Water Solubility.

National Standardization Agency of Indonesia.

Indonesia National Standard (SNI). 1990. SNI 14-1838:

Test Method for One Percent Sodium Hydroxide

of Pulp Wood Solubility. National Standardization

Agency of Indonesia.

Indonesia National Standard (SNI). 2005. SNI 08-7070:

Method of Test for Moisture Content of Pulp and

Wood by heating in the oven. National Standardization

Agency of Indonesia.

Iswanto, A.H., Susilowati, A., Azhar, I., Riswan, Supriyanto, Tarigan, J.E., Fatriasari, W. 2016. Physical and mechanical properties of local styrax wood from north tapanuli, in indonesia. Journal of the Korean Wood Science and Technology 44(4): 539-550.

Iswanto, A.H., Siregar, Y.S., Susilowati, A., Darwis, A., Hartono, R., Wirjosentono, B., Rahmat, H.H., Hidayat, A., Fatriasari, W. 2019. Variation in chemical constituent of Styrax sumatrana wood growing at different cultivation site in North Sumatra, Indonesia. Biodiversitas 20(2): 448-452.

Jasni, Pari, G., Satiti, E.R. 2016. Chemical composition and natural durability of 20 indonesian wood species tested under the shade. Jurnal Penelitian Hasil Hutan 34(4): 323-333.

Kiswandono, A.A., Iswanto, A.H., Susilowati, A., Lumbantobing, A.F. 2016. Analysis of the Content of Cinnamic Acid and Phytochemical Screening Sap Incense Species of Bulu (Styrax benzoine var. Hiliferum) of North Tapanuli. Proceeding of National Seminar of Chemical 2016, Mataram, Indonesia, 10-11 August 2016; Universitas Mataram: Indonesia.

Kollman, F.F.P., Cote, W.A. 1984. Principle of Wood Science and Technology, Volume I: Solid Wood. Berlin, Heidelberg, New York, Tokyo: Springer-Verlag.

Lee, H.W., Jeong, H., Ju, Y.-M., Youe, W.-J., Lee,
J., Lee, S.M. 2019. Pyrolysis properties of lignins extracted from different biorefinery processes. Journal of the Korean Wood Science and Technology 47(4): 486-497.

Lestari, E., Pramasari, D.A., Amin, Y., Adi, D.S., Bahanawan, A., Dwianto, W. 2016. The Chemical Components Changes Of Platinum Teak Wood. Proceedings of The 6th International Symposium for Sustainable Humanosphere Humanosphere Science School 2016 pp. 164-170.

Li, Q., Zhu, Y.Q., Eichhorn, S.J. 2018. Structural supercapacitors using a solid resin electrolyte with carbonized electrospun cellulose/carbon nanotube electrodes. Journal of Materials Science 53: 14598-14607.

Liu, Z.-H., Hao, N., Shinde, S., Pu, Y., Kang, X., Ragauskas, J.A., Yuan, S.J. 2019. Defining Lignin Nanoparticle Properties through Tailored Lignin Reactivity by Sequential Organosolv Fragmentation Approach (SOFA). Green Chemistry 2: 245-260.

Lukmandaru, G. 2016. Correlation between extractive content and colour properties in teak heartwood. Jurnal Penelitian Hasil Hutan 34(3): 207-216.

Lukmandaru, G., Zumaini, U.F., Soeprijadi, D., Nugroho, W.D., Susanto, M. 2016. Chemical properties and fiber dimension of Eucalyptus pellita from The 2nd generation of progeny tests in pelaihari, south borneo, indonesia. Journal of the Korean Wood Science and Technology 44(4): 571-588.

MacLeod, M. 2007. The top ten factors in kraft pulp yield. Paper and Timber 89(4): 1-7.

Maulina, S., Handika, G., Irvan., Iswanto, A.H. 2020. Quality comparison of activated carbon produced from oil palm fronds by chemical activation using sodium carbonate versus sodium chloride. Journal of the Korean Wood Science and Technology 48(4): 503-512.

Mietner, J.B., Jiang, X., Edlund, U., Saake, B., Navarro, J.R.G. 2021. 3D printing of a bio-based ink made 
Apri Heri ISWANTO $\cdot$ Fazilla Oktaviani TARIGAN $\cdot$ Arida SUSILOWATI $\cdot$ Atmawi DARWIS $\cdot$ Widya FATRIASARI

of cross-linked cellulose nanofibrils with various metal cations. Scientific Reports 11: 6461.

Ministry of Environment and Forestry. 2020. Vademecum Kehutanan Indonesia 2020; Ministry of Environment and Forestry: Jakarta, Indonesia, pp. 319.

Martawijaya, A., Kartasujana, I., Kadir, K., Prawira, S.A. 2005. Atlas Kayu Indonesia Jilid I; Forest Research and Development Agency: Bogor, Indonesia, pp. 1-171.

Ona, T., Sonoda, T., Ito, K., Shibata, M. 1998. Relations between various extracted basic densities and wood chemical components in Eucalyptus globulus. Journal of Wood Science 44: 165-168.

Pari, G., Roliadi, H., Setiawan, D., Saepuloh. 2006. Chemical component of ten planted wood species originated from west java. Jurnal Penelitian Hasil Hutan 24(2): 89-101

Park, S.-Y., Kim, J.-C., Kim, J.-H., Yang, S.-Y., Kwon, O., Yeo, H., Cho, K.-C., Choi, I.-G. 2017. Possibility of wood classification in Korean softwood species using near-infrared spectroscopy based on their chemical compositions. Journal of the Korean Wood Science and Technology 45(2): 202-212.

Pasaribu, G. 2007. Physical and mechanical properties of four endemic wood species from north sumatra. Jurnal Penelitian Hasil Hutan 25(1): 15-27.

Pasaribu, G., Sipayung, B., Pari, G. 2007. Chemical component analysis of four endemic wood species from north sumatra. Jurnal Penelitian Hasil Hutan 25(4): 327-333.

Pettersen, R.C. 1984. The Chemical Composition of Wood. In The Chemistry of Solid Wood. Rowell, R. American Chemical Society: USA, pp. 57-126. Purnamawati, R., Febrianto, F., Wistara, I.N.J., Nikmatin, S., Hidayat, W., Lee, S.H., Kim, N.H. 2018. Physical and chemical properties of kapok (Ceiba pentandra) and balsa (Ochroma pyramidale) fibers. Journal of the Korean Wood Science and Technology 46(4):
393-401.

Purwita, C.A., Sugesty, S. 2018. Preparation and characterization of long fiber dissolving pulp from spiny bamboo (Bambusa blumeana). Jurnal Selulosa 8(1): 21-32.

Rahman, W.M.N.W.A., Yunus, N.Y.M., Kasim, J., Tamat, N.S.M. 2018. Effects of tree porsion and radial position on physical and chemical properties of kelampayan (Neolamarckia cadamba) wood. Bioresources 13(2): 4536-4549.

Rahmat, H.H., Susilowati, A., Elfiati, D., Hartini, K.S., Faradillah, W.N. 2017. Strong genetic differentiation of the endemic rosin-producing tree Styrax sumatrana (Styracaceae) in North Sumatra, Indonesia. Biodiversitas 18(4): 1331-1335.

Ray, D., Das, M., Mitra, D. 2009. Influence of alkali treatment on creep properties and crystalinity of jute fibres. Bioresources 4(2): 730-739.

Siagian, R.M., Darmawan, S., Saepuloh. 1999. Chemical composition of acacia mangium willd at several ages harvested from first rotation growth. Buletin Penelitian Hasil Hutan 17(1): 57-66.

Siddiqui, L., Mishra, H., Mishra, P.K., Iqbal, Z., Talegaonkar, S. 2018. Novel 4-in-1 strategy to combat colon cancer, drug resistance and cancer relapse utilizing functionalized bioinspiring lignin nanoparticle. Medical Hypotheses 121: 10-14.

Sinaga, M.Z.E., Susilowati, A., Sebayang, F., Ginting, S.E., and Suhartati, T. 2020. Antioxidant and antihyperuricemic potentials of raru (Cotylelobium melanoxylon Pierre) bark. Rasayan Journal of Chemistry 13(4): 2569-2576.

Sjöström, E. 1993. Wood Chemistry. Fundamentals and Applications; Academic Press: New York, USA, pp. 1-293.

Stephenson, J. 1951. Pulp and Paper Manufacture: Preparation of Stack for making paper; Mc Grow Hill Book Companny, Inc: NewYork, USA.

Sumada, K., Tamara, P.E., Alqani, F. 2011. Isolation 
Wood Chemical Compositions of Raru Species Originating from Central Tapanuli, North Sumatra, Indonesia: Effect of Differences in Wood Species and Log Positions

study of efficient A-Cellulose from waste plant stem manihot esculenta crantz. Jurnal Teknik Kimia 5(2): 434-438.

Susilowati, A., Rachmat, H.H., Kholibrina, C.R., Munthe, M.A. 2018. Phylogeny of kemenyan (Styrax sp) based on morphological character. IOP Conference Series: Earth and Environmental Science 122: 012062.

Susilowati, A., Iswanto, A.H., Kusuma, Y.S., Rachmat, H.H., Elfiati, D., Larengkeng, S.H., Ginting' I.M., and Rangkuti, A.B. 2020. Morphological identification of local raru producing trees from sibuluan nauli, central tapanuli, North Sumatera. IOP Conference Series: Earth and Environmental Science 454: 012155 .

Susilowati, A., Rachmat, H.H., Elfiati, D., Kholibrina, R.C., Kusuma, S.Y., Siregar, H. 2019. Population structure of Cotylelobium melanoxylon within vegetation community in Bonalumban forest, Central Tapanuli, North Sumatra, Indonesia. Biodiversitas 20(6): 1681-1687.

Susilowati, A., Hartini, K.S., Elfiati, D., Rachmat, H.H., Kusuma, S.Y., Sinaga, M.Z.E., Suhartati, T. 2020. Conservation of tropical tree biodiversity through macropropagation by shoot cutting of raru (Cotylelobium melanoxylon), a highly utilized dipterocarp in North Sumatra, Indonesia. Biodiversitas 21(2): 724-730.

Syafii, W., Siregar, I.Z. 2006. Chemical properties and fiber dimension of Acacia mangium willd. from three provenances. Journal of Tropical Wood Science and Technology 4(1): 28-32.

Terashima, N., Kitano, K., Kojima, M., Yoshida, M., Yamamoto, H., Westermark, U. 2009. Nanostructural assembly of cellulose, hemicellulose, and lignin in the middle layer of secondary wall of Ginkgo Tracheid. Journal of Wood Science 55: 409-416.

Tzeng, P., Hewson, D.J., Vukusic, P., Eichhorn, S.J., Grunlan, J.C. 2015. Bio-Inspired iridescent layer-bylayer-assembled cellulose nanocrystal Bragg Stacks. Journal of Materials Chemistry 3(17): 4260-4264.

Xiao, D., Ding, W., Zhang, J., Ge, Y., Wu, Z., Li, Z. 2019. Fabrication of a versatile lignin-based nano-trap for heavy metal ion capture and bacterial inhibition. Chemical Engineering Journal 358: 310-320.

Xing, Q., Buono, P., Ruch, D., Dubois, P., Wu, L., Wang, W.-J. 2019. Biodegradable UV-blocking films through core-shell lignin-melanin nanoparticles in poly(butylene adipate-co-terephthalate). ACS Sustainable Chemistry \& Engineering 7(4) 4147-4157. Yang, I., Jeong, H., Lee, J.J., Lee, S.M. 2019. Relationship between lignin content and the durability of wood pellets fabricated using Larix kaempferi C. Sawdust. Journal of the Korean Wood Science and Technology 47(1): 110-123.

Yunanta, R.R.K., Lukmandaru, G., Fernandez, A. 2014. Chemical properties of Shorea retusa, Shorea macroptera, and Shorea macrophylla Woods. Jurnal Dipterokarpa 8(1): 15-24.

Zikeli, F., Vinciguerra, V., D’Annibale, A., Capitani, D., Romagnoli, M., Scarascia Mugnozza, G. 2019. Preparation of lignin nanoparticles from wood waste for wood surface treatment. Nanomaterials $9(2)$ : 281 . 